\title{
Phenolic contents, antioxidant and anticholinesterase potentials of crude extract, subsequent fractions and crude saponins from Polygonum hydropiper $\mathrm{L}$
}

Muhammad Ayaz ${ }^{1 *}$, Muhammad Junaid ${ }^{1}$, Jawad Ahmed², Farhat Ullah¹, Abdul Sadiq ${ }^{1}$, Sajjad Ahmad ${ }^{1}$ and Muhammad Imran

\begin{abstract}
Background: We investigated Polygonum hydropiper L. (P. hydropiper) for phenolic contents, antioxidant, anticholinesterase activities, in an attempt to rationalize its use in neurological disorders.

Methods: Plant crude extract (Ph.Cr), its subsequent fractions: $n$-hexane (Ph.Hex), chloroform (Ph.Chf), ethyl acetate (Ph.EtAc), n-Butanol (Ph.Bt), aqueous (Ph.Aq) and saponins (Ph.Sp) were evaluated for 1,1-diphenyl,2-picrylhydrazyl (DPPH), 2,2-azinobis[3-ethylbenzthiazoline]-6-sulfonic acid (ABTS) free radical scavenging potential. Further, acetylcholinesterase (AChE) \& butyrylcholinesterase (BChE) inhibitory activities were performed using Ellman's assay. Moreover, total phenolic contents of plant extracts were determined and expressed in $\mathrm{mg}$ of gallic acid equivalent per gram of dry sample (mg GAE/g dry weight).

Results: Among different fractions, Ph.Cr (90.82), Ph.Chf (178.16), Ph.EtAc (203.44) and Ph.Bt (153.61) exhibited high phenolic contents. All fractions showed concentration dependent DPPH scavenging activity, with Ph.EtAc 71.33\% (IC $5015 \mu \mathrm{g} / \mathrm{ml})$, Ph.Bt 71.40\% $\left(\mathrm{IC}_{50} 3 \mu \mathrm{g} / \mathrm{ml}\right)$ and Ph.Sp 71.40\% $\left(I \mathrm{C}_{50} 35 \mathrm{\mu g} / \mathrm{ml}\right)$ were most potent. The plant extracts exhibited high ABTS scavenging ability i.e. Ph.Bt (91.03\%), Ph.EtAc (90.56\%), Ph.Sp (90.84\%), Ph.Aq (90.56\%) with $\mathrm{IC}_{50}<0.01 \mathrm{\mu g} / \mathrm{ml}$. All fractions showed moderate to high AChE inhibitory activity as; Ph.Cr, $86.87 \%$ (IC $50330 \mu \mathrm{g} / \mathrm{ml})$, Ph.Hex, 87.49\% (IC $5035 \mu \mathrm{g} / \mathrm{ml})$, Ph.Chf, 84.76\% (IC $5055 \mu \mathrm{g} / \mathrm{ml})$, Ph.Sp, 87.58\% (IC $50108 \mu \mathrm{g} / \mathrm{ml})$ and Ph.EtAc $79.95 \%\left(\mathrm{IC}_{50} 310 \mathrm{\mu g} / \mathrm{ml}\right)$ at $\left.1 \mathrm{mg} / \mathrm{ml}\right)$. Furthermore the BChE inhibitory activity was most prominent in Ph.Hex 90.30\% (IC $5040 \mu \mathrm{g} / \mathrm{ml})$, Ph.Chf 85.94\% (IC $50215 \mu \mathrm{g} / \mathrm{ml})$, Ph.Aq 87.62\% (IC $503 \mu \mathrm{g} / \mathrm{ml})$ and Ph.EtAc $81.01 \%\left(\mathrm{C}_{50} 395 \mu \mathrm{g} / \mathrm{ml}\right)$ fractions.

Conclusions: In this study, for the first time, we determined phenolic contents, isolated crude saponins, investigated antioxidant and anticholinestrase potential of $P$. hydropiper extracts. The results indicate that $P$. hydropiper is enriched with potent bioactive compounds and warrant further investigation by isolation and structural elucidation to find novel and affordable compounds for the treatment of various neurological disorders.
\end{abstract}

Keywords: DPPH, ABTS, Gallic acid, Polygonum hydropiper L

\footnotetext{
* Correspondence: ayazuop@gmail.com

'Department of Pharmacy, University of Malakand, Khyber Pakhtoonkhwa 18000, KPK, Pakistan

Full list of author information is available at the end of the article
} 


\section{Background}

Medicinal plants are nature's gift and are necessary for disease-free \& healthy life of human beings. Since ancient times, plants have been employed for prevention and treatment of a variety of ailments. There has been a great revival in the use of herbal remedies particularly in last decades. According to World Health Organization (WHO), approximately eighty percent of the world population relies on medicinal plants to meet their primary health care [1]. P. hydropiper, also called Smartweed (family polygonaceae), has a long history of herbal use, equally in Eastern \& Western herbal medicine. Domestically, it is used as anti-inflammatory, carminative, astringent, diuretic, CNS stimulant, diaphoretic, stomachic, styptic, in bleeding and in diarrhea [2]. The plant is enriched with rutin which strengthens fragile blood vessels and helps in the prevention of bleeding [3]. Traditionally, the whole plant decoction is used to treat an extensive range of ailments like dyspepsia, diarrhea, menorrhagia, hemorrhoids and skin itching [4]. Recently antioxidant flavonoids have been isolated from leaves of P. hydropiper [5]. Other species of polygonaceae family have been reported for their effectiveness in cerebral ischemia [6], parkinson's disease [7] and neuroprotective effects [8].

Free radicals are implicated in the progression of a variety of disorders in humans including central nervous system injury, arthritis, atherosclerosis, ischemic heart diseases, gastritis, cancer and reperfusion injury of many tissues $[9,10]$. Free radicals from environmental pollutants, chemical agents, radiations, toxins, spicy and deep fried foods cause reduction of immune system antioxidants, alter gene expression along with induction of abnormal proteins. Free radicals are generated in living systems during oxidation process. To counteract oxidative stress, catalase and hydroperoxidase enzymes in human body convert hydrogen peroxide and hydroperoxides to nonradical forms and hence work as natural antioxidants. Thus, due to depletion of human immune system, natural antioxidants as free radical scavengers may be necessary $[11,12]$. Presently available synthetic antioxidants including butylated hydroxy toluene (BHT), butylated hydroxy anisole (BHA), gallic acid esters and tertiary butylated hydroquinon have been alleged to be associated with negative health consequences. Hence, their use is restricted and there is a tendency to substitute them with natural antioxidants [13]. Numerous reports on the antioxidant and radical-scavenging activities of crude extracts and pure natural compounds have been published [10,14]. Among the antioxidant compounds, significant attention has been given to phenolic compounds and flavonoids. Phenolic compounds, due to the existence of the conjugated ring structures and hydroxyl groups, have the potential to function as antioxidants by scavenging the free radicals that are involved in oxidative processes via hydrogenation or complexation with oxidizing species [15].

Acetylcholinesterase $(\mathrm{AChE})$ and butyrylesterase $(\mathrm{BChE})$ are useful targets for the development of novel and mechanism based inhibitors, due to its role in the breakdown of acetylcholine $(\mathrm{ACh})$ neurotransmitter. Inhibitors of $\mathrm{AChE}$ and $\mathrm{BChE}$ enzymes are the most valuable approaches to treat neurological diseases including Alzheimer's disease (AD) [16] and possible beneficial applications in the treatment of Parkinson's disease, ataxia and dementia [17]. AD is a persistent neurological disorder frequently associated with memory impairment, behavioral turbulence, cognitive dysfunction and imperfection in routine life activities $[18,19]$. This disease results from malfunctioning of different biochemical pathways resulting in a significant decline in ACh amount [20]. ACh is involved in signal transmission in the synapse and its pharmacological action is terminated primarily by $\mathrm{AChE}$ and secondly by $\mathrm{BChE}$ [21]. Therefore inhibitors of these metabolizing enzymes have become the important alternatives in treatment of $\mathrm{AD}$ and other neurological diseases. Conversely, presently available drugs are associated with serious side effects including hepatotoxicity [22] and are only effective in mild type of $\mathrm{AD}$ [23]. Consequently, it is necessary to embark new, safe and effective drug candidates. Plants are potential sources of novel active compounds and have a long history of therapeutic use since the beginning of human era. Galanthamine, an anticholinestrase alkaloid isolated from snowdrop, has been recently approved for the treatment of $\mathrm{AD}$ [24]. Research has been focused on the biological effects of plants which have been traditionally used as cholinesterase inhibitors in-vitro as well as in-vivo [24,25]. This study is focused on preliminary anticholinestrase and antioxidant potential of $P$. hydropiper.

\section{Methods}

\section{Plant Collection, Extraction and Fractionation}

$P$. hydropiper whole plant was collected from Talash Valley, Khyber Pakhtoonkhwa, Pakistan in July, 2013. The plant was identified by botanical taxonomist at Arid agriculture University, Rawalpindi, Pakistan and a sample was deposited at the herbarium, University of Malakand Chakdara (Dir), Pakistan with voucher no (H.UOM.BG.107). Plant material was cleansed with distilled water and was shade dried for 15 days. Thereafter, it was coarsely crushed using cutter mill. The powder material $(4.5 \mathrm{~kg})$ was soaked in $80 \%$ methanol $(22 \mathrm{~L})$ for 10 days with frequent shaking. Extraction with methanol was repeated three times, added to original extract and filtered through muslin cloth and then through filter [26]. The filtrate was concentrated using rotary evaporator (Heidolph Laborota 4000, Schwabach, Germany) under reduced pressure at $40^{\circ} \mathrm{C}$ resulting in $290 \mathrm{~g}(6.44 \%)$ of dark brown colored semisolid mass. Crude methanolic 
extract $(250 \mathrm{~g})$ of $P$. hydropiper $(\mathrm{Ph}-\mathrm{Cr})$ was suspended in $500 \mathrm{ml}$ of distilled water and consequently partitioned with $n$-hexane $(3 \times 500 \mathrm{ml})$, chloroform $(3 \times 500 \mathrm{ml})$, ethyl acetate $(3 \times 500 \mathrm{ml}), n$-butanol $(3 \times 500 \mathrm{ml})$ and aqueous $(3 \times 500 \mathrm{ml})$, using separating funnels. Finally, 68g (27.2\%) Ph.Hex, 27g (10.8\%) Ph.Chf, 13g (5.2\%) Ph. EtAc, 11 g (4.4\%) Ph.Bt \& 37 g (14.8\%) Ph.Aq fractions were obtained.

\section{Extraction of crude saponins}

A portion of powdered plant material, weighing $60 \mathrm{~g}$, was transferred to a conical flask and was soaked with $100 \mathrm{ml}$ of $20 \%$ ethanol. The mixture was heated for $4 \mathrm{~h}$ at a temperature of $55^{\circ} \mathrm{C}$ using water bath and constant shaking. Thereafter, it was filtered and was again extracted with $200 \mathrm{ml}$ of $20 \%$ ethanol. Volume of the liquid extract was reduced to $40 \mathrm{ml}$ using water bath and transferred it to a separating funnel. Diethyl ether $(20 \mathrm{ml})$ was added to it with vigorous shaking until two layers were formed. Organic layer was discarded, whereas $60 \mathrm{ml}$ of $n$-butanol was added to aqueous fraction. The combined aqueous-butanol mixture was washed with 5\% $\mathrm{NaCl}$ solution two times. Finally solvents were evaporated using water bath to get saponins ( $9 \mathrm{~g}$ ) with a percent yield of $15 \%$ [27].

\section{Chemical and Drugs}

DPPH (CAS 1898-66-4 Sigma Aldrich CHEMIE GmbH USA), ABTS (CAS 30931-67-0 Sigma Aldrich USA), $\mathrm{K}_{2} \mathrm{~S}_{2} \mathrm{O}_{4}$ (Riedel-de Haen Germany), Gallic acid (CAS 149-91-7 GmbH USA) and Folin Ciocalteu reagent (FCR) was purchased from Merck Co. (Germany). Enzymes including AChE Electric eel (type-VI-S, CAS 9000-81-1 Sigma-Aldrich GmbH USA), BChE equine serum Lyophilized (CAS 9001-08-5 Sigma-Aldrich GmbH USA), substrates acetylthiocholine iodide (CAS1866-15-5 SigmaAldrich UK), butyrylthiocholine Iodide CAS 2494-56-6 Sigma-Aldrich Switzerland), DTNB 5,5-dithio-bis-nitrobenzoic acid (CAS 69-78-3 Sigma-Aldrich Germany), Galanthamine hydrobromide Lycoris Sp. (CAS 1953-04-4 Sigma-Aldrich France) were used for enzyme inhibition study. For preparation of buffer, di-potassium hydrogen phosphate $\left(\mathrm{K}_{2} \mathrm{HPO}_{4}\right)$, Potassium di-hydrogen phosphate $\left(\mathrm{KH} 2 \mathrm{PO}_{4}\right)$, potassium hydroxide used were of extra pure analytical grade.

\section{Total phenolic contents}

Total phenolic contents of the fractions were investigated using procedure adopted by Kim et al., [28]. One $\mathrm{ml}$ from each concentration of the plant extract was added to $9 \mathrm{ml}$ distilled water followed by addition of $1 \mathrm{ml} \mathrm{FCR} \mathrm{with} \mathrm{vigorous} \mathrm{shaking.} \mathrm{After} \mathrm{five} \mathrm{minutes,}$ $10 \mathrm{ml}$ of $7 \% \mathrm{Na}_{2} \mathrm{CO}_{3}$ solution was added to the tube and mixed properly. Distilled water $(25 \mathrm{ml})$ was added to this mixture and analyzed after 90 minutes using spectrophotometer (Thermo electron corporation, USA) at $750 \mathrm{~nm}$. Finally gallic acid ( $97.5 \%$ pure) standard curve was employed to quantify total phenolic contents and were expressed as mg equivalent of gallic acid.

\section{DPPH radical scavenging assay}

Free radical scavenging ability of the samples, based on the scavenging activity of 1,1-diphenyl,2-picrylhydrazyl $(\mathrm{DPPH})$ free radical, was evaluated using the procedure described previously [29]. Different dilutions (125, 250, 500 and $1000 \mu \mathrm{g} / \mathrm{ml})$ of plant extract $(0.1 \mathrm{ml})$ were added to $0.004 \%$ methanolic solution of DPPH. After 30 minutes, absorbance was determined at $517 \mathrm{~nm}$ using UV spectrophotometer. Ascorbic acid was used as positive control, percent scavenging activity was calculated as; $\left[\left(A_{0}-A_{1}\right) / A_{0}\right] \times 100$, where $A_{0}$ represent absorbance of control and $A_{1}$ is the absorbance of the plant extracts. Each experiment was done in triplicate and inhibition graphs were constructed using the GraphPad prism program (GraphPAD, San Diego, California, USA) and median inhibitory concentrations $\mathrm{IC}_{50}$ values were determined.

\section{ABTS free radical scavenging assay}

The antioxidant potential of $P$. hydropiper was also evaluated using 2, 2-azinobis [3-ethylbenzthiazoline]6-sulfonic acid (ABTS) [30]. The assay is based on the capacity of antioxidants to scavenge ABTS radical cation causing a reduction in absorbance at $734 \mathrm{~nm}$. briefly, ABTS $7 \mathrm{mM}$ and potassium persulphate $\left(\mathrm{K}_{2} \mathrm{~S}_{2} \mathrm{O}_{4}\right)$ $2.45 \mathrm{mM}$ solutions were prepared and mixed. The resultant mixture was stored in dark at room temperature for 12-16 h to get dark colored solution containing ABTS radical cations. Prior to use, ABTS radical cation solution was diluted with Phosphate buffer $(0.01 \mathrm{M}) \mathrm{pH}$ 7.4, to adjust an absorbance value of 0.70 at $734 \mathrm{~nm}$. Radical scavenging ability of the fractions was analyzed by mixing $300 \mu \mathrm{l}$ of test sample with $3.0 \mathrm{ml}$ of ABTS solution in cuvette. The reduction in absorbance was measured spectrophotometrically after one minute of mixing the solutions and continued for six min. Ascorbic acid was used as positive control. The assay was repeated in triplicate and percentage inhibition was calculated using formula:

$$
\begin{aligned}
\% \text { scavenging effect }= & \text { control absorbance } \\
& - \text { sample absorbance } \\
& / \text { control absorbance } \times 100
\end{aligned}
$$

The antioxidant effect was expressed in terms of percent inhibition and as $\mathrm{EC}_{50}$ (Extract concentration required for $50 \%$ reduction of ABTS radicals). 


\section{Anticholinesterase assays}

AChE from Electric eel and BChE from equine serum were used to explore the enzymes inhibitory potential of $\mathrm{Ph} . \mathrm{Cr}$ of $P$. hydropiper, its subsequent fractions and $\mathrm{Ph}$. Sp using Ellman's assay [31,32]. The assay is based on the hydrolysis of acetylthiocholine iodide or butyrylthiocholine iodide by the respective enzymes and the formation of 5-thio-2-nitrobenzoate anion followed by complexation with DTNB to give yellow color compound which is detected with spectrophotometer beside the reaction time.

\section{Preparation of solutions}

$\mathrm{Ph} . \mathrm{Cr}$ and subsequent fractions were dissolved in phosphate buffer $(0.1 \mathrm{M})$ in concentrations ranging from $125-1000 \mu \mathrm{g} / \mathrm{ml}$. For the preparation of $0.1 \mathrm{M}$ and $8.0 \pm 0.1 \mathrm{pH}$ phosphate buffer solution, $\mathrm{K}_{2} \mathrm{HPO}_{4}(17.4 \mathrm{~g} / \mathrm{L})$ and $\mathrm{KH}_{2} \mathrm{PO}_{4}(13.6 \mathrm{~g} / \mathrm{L})$ were prepared and were mixed in $94 \%$ and $6 \%$ ratio respectively. Finally, potassium hydroxide was used to adjust PH. AChE (518U/mg solid) and BChE (7-16U/mg) were diluted in freshly prepared buffer $\mathrm{pH} 8.0$ until final concentrations of $0.03 \mathrm{U} / \mathrm{ml}$ and $0.01 \mathrm{U} / \mathrm{ml}$ were obtained. Solutions of DTNB $(0.0002273 \mathrm{M})$, ATchI and BTchI $(0.0005 \mathrm{M})$ were prepared in distilled water and were kept in eppendorf caps in the refrigerator at $8^{\circ} \mathrm{C}$. Galanthamine (Positive control) was dissolved in methanol and the aforementioned dilutions were prepared.

\section{Spectroscopic analysis}

For each assay, an enzyme solution of $5 \mu \mathrm{l}$ was added to the cuvette followed by addition of plant extract solution $(205 \mu \mathrm{l})$, and finally DTNB reagent $(5 \mu \mathrm{l})$. The solution mixture was maintained at $30^{\circ} \mathrm{C}$ for 15 min using water bath with subsequent addition of substrate solution $(5 \mu \mathrm{l})$ was added. A double beam spectrophotometer (Thermo electron corporation USA) was used to measure the absorbance at $412 \mathrm{~nm}$. Negative control contained all components apart from the plant extracts, whereas positive control galanthamine $(10 \mu \mathrm{g} / \mathrm{ml})$ was used in the assay as standard cholinesterase inhibitor. The absorbances along with the reaction time were taken for four minutes at $30^{\circ} \mathrm{C}$. The experiments were performed in triplicate. The enzyme activity and enzyme inhibition by control and tested samples were calculated from the rate of absorption with change in time $(\mathrm{V}=\Delta \mathrm{Abs} / \Delta \mathrm{t})$ as follow;

Enzyme inhibition (\%) $=100$ - percent enzyme activity

Enzyme activity (\%) $=100 \times \mathrm{V} / \mathrm{V} \max$ where $(\mathrm{Vmax})$ is enzyme activity in the absence of inhibitor drug.

\section{Estimation of $\mathrm{IC}_{50}$ values}

Concentrations of the plant extracts which inhibited substrate hydrolysis ( $\mathrm{AChE}$ and $\mathrm{BChE})$ by $50 \%\left(\mathrm{IC}_{50}\right)$.
Radical scavenging ability was calculated by a linear regression analysis among the percent inhibition against the extract concentrations via Excel program.

\section{Statistical data analysis}

All the assays were repeated in triplicate and vales were expressed as means \pm S.E.M. Significance between antioxidant activity and plant extracts were analyzed using Mann-Whitney U test. Group comparison was done using Student's $t$-test. The P values less than 0.05 were considered as statistically significant.

\section{Results}

\section{Total phenolic content}

The extraction yield of phenolics (mg GAE/g of sample) in different fractions of the plant extracts are summarized in Figure 1. Ph.EtAc and Ph.Chf exhibited high phenolic contents as compared to other fractions. The concentration of phenolics among different fractions were in an ascending order of Ph.EtAc $>\mathrm{Ph}$.Chf $>$ $\mathrm{Ph} . \mathrm{Bt}>\mathrm{Ph} . \mathrm{Cr}>\mathrm{Ph} . \mathrm{Aq}>\mathrm{Ph}$.Hex.

\section{DPPH Free radical scavenging potential}

In the DPPH free radical scavenging assay, all fractions showed concentration dependent inhibition of the free radicals as shown in Figure 2. Among different fractions, Ph.EtAc, Ph.Bt and Ph.Chf showed highest activity which can be attributed to their high phenolic contents. Ph.Bt, Ph.Chf and Ph.EtAc fractions were most potent with $\mathrm{IC}_{50}$ of 3,10 and $15 \mu \mathrm{g} / \mathrm{ml}$ respectively. The DPPH free radical scavenging potential of the tested fractions were in an ascending order of $\mathrm{Ph}$. EtAc $>$ Ph. Bt $>$ Ph.Chf $>$ Ph.Sp $>$ Ph.Cr $>$ Ph. Hex $>$ Ph.Aq. In comparison to positive control, $\mathrm{Ph} . \mathrm{Cr}$, Ph.Hex, Ph. $\mathrm{Chf}$, Ph.Aq and $\mathrm{Ph} . \mathrm{Sp}$ percent inhibitions were significantly

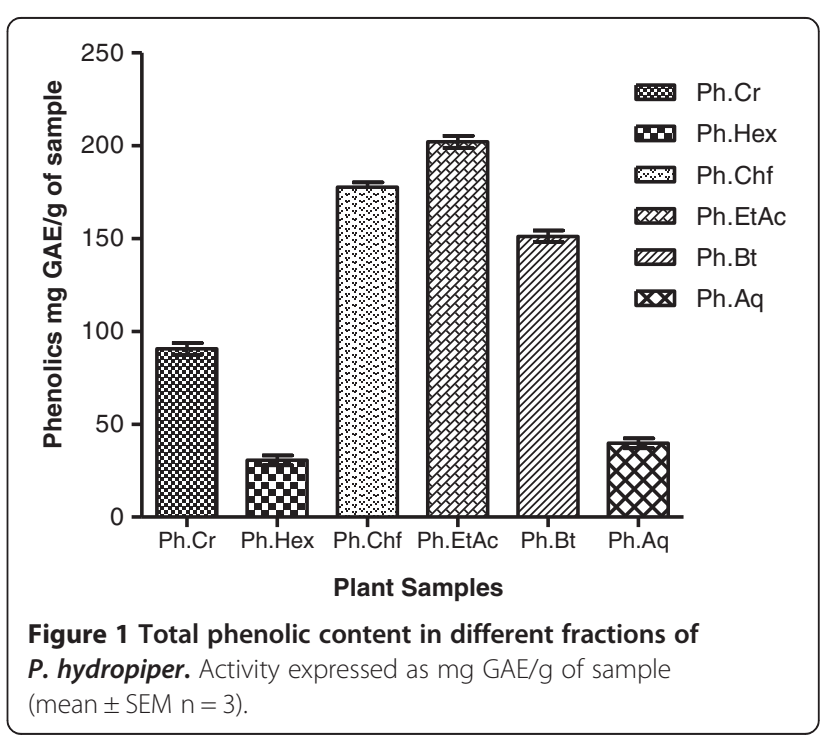




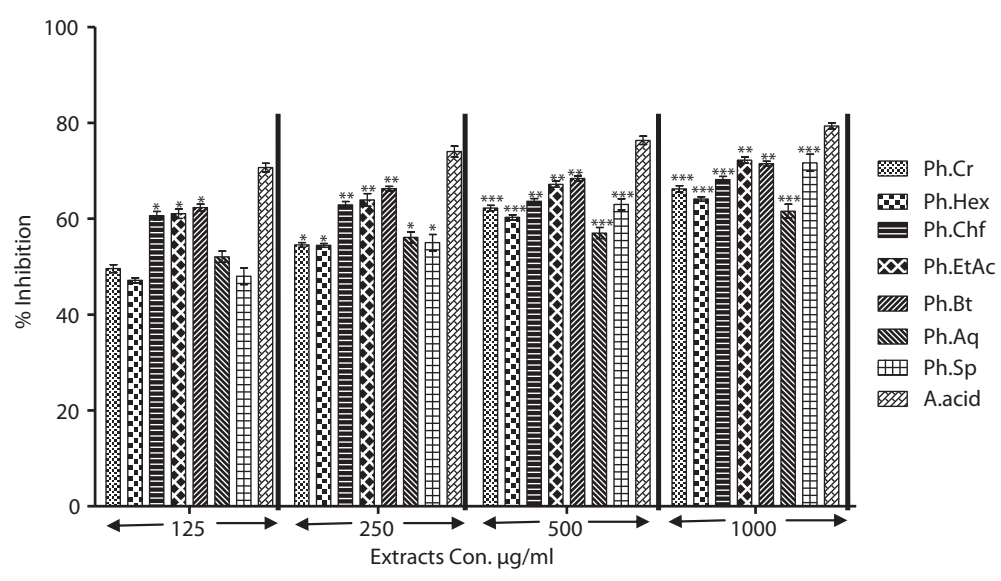

Figure 2 Antioxidant assay of plant extracts using DPPH assay. Values represent\% radical scavenging (mean \pm SEM) of three replicates. Values significantly different as compare to positive control, ${ }^{*} \mathrm{P}<0.05$, ${ }^{* * P}<0.01$, ${ }^{* *} \mathrm{P}<0.001$.

different $\mathrm{P}<0.001$ at highest concentration of extracts $(1000 \mu \mathrm{g} / \mathrm{ml})$.

\section{ABTS Free radical scavenging assay}

Results of ABTS free radical scavenging assay are given in Table 1. Plant extracts revealed high ABTS free radical scavenging activity in comparison to DPPH. Among different fractions, Ph.Bt, Ph.EtAc, Ph.Aq, Ph.Sp revealed highest ABTS scavenging activity causing 91.03, 90.65, 90.56 and $90.84 \%$ inhibition of free radicals respectively. The scavenging activity of these fractions were comparable with the positive control ascorbic acid with $\mathrm{IC}_{50}$ values of $0.01 \mu \mathrm{g} / \mathrm{ml}$.

\section{Acetylcholinesterase Inhibition assay}

Among different fractions of $P$. hydropiper, Ph.Sp, Ph. Hex and Ph.Cr fractions showed strongest activity causing 87.58, 87.49 and $86.87 \%$ inhibition of AChE. All fractions were effective in concentration dependent manner as summarized in Table 2. Ph.Hex, Ph.Chf and Ph.Sp were most potent displaying median inhibitory values $\left(\mathrm{IC}_{50}\right)$ of 35,55 and $100 \mu \mathrm{g} / \mathrm{ml}$. Whereas the $\mathrm{IC}_{50}$ value for positive control galanthamine was $0.1 \mu \mathrm{g} / \mathrm{ml}$. The AChE inhibitory activity of the tested fractions were in an ascending order of Ph.Sp $>$ Ph.Hex $>\mathrm{Ph} . \mathrm{Cr}>\mathrm{Ph} . \mathrm{Chf}>$ Ph.EtAc $>$ Ph.Bt $>$ Ph.Aq.

\section{Butyrylcholinesterase inhibition assay}

BChE inhibitory activity was most prominent for, $\mathrm{Ph}$. Hex, Ph.Aq, Ph.Chf and Ph.EtAc fractions at $1 \mathrm{mg} / \mathrm{ml}$ concentration. Results are given in Table 3. Ph.Hex, Ph. Aq and Ph.Chf exhibited 90.30, 87.62 and 85.94\% inhibition of BChE which is comparable to positive cotrol galantamine causing 96\% enzyme inhibition at the same concentration (1 mg/ml). Whereas Ph.Aq and Ph.Hex were more potent with $\mathrm{IC}_{50}$ values of 3 and $40 \mu \mathrm{g} / \mathrm{ml}$.

\section{Discussion}

Discovery and development of new antioxidant drugs is among the most exciting areas of pharmacological research. Oxygen is a vital element of aerobic life, but under certain conditions it can seriously influence our health by formation of reactive oxygen species (free radicals) leading to some potentially dangerous diseases, like coronary heart disease, diabetes, atherosclerosis, neurodegenerative disorders (AD \& Dementia), cancer, immune-suppression, ageing and ulcer [33,34]. Most common free radicals include hydroxyl, nitric oxide, superoxide \& lipid peroxyl, whereas non-free radicals primarily include singlet oxygen and hydrogen peroxide [35]. Nevertheless, approximately all living organisms are protected from free radicals attack by defense system, such as a protective antioxidant system that diminish the rate of free radical formation along with another system which create chain-breaking antioxidants to scavenge \& stabilize free radicals. However, when the rate of free radical generation exceeds the capacity of defense mechanisms, extensive tissue injury results [36]. Consequently, drugs with free radical scavenging abilities are useful for the prevention and therapy of these diseases [37]. Antioxidant compounds are known to show their biochemical effects via several mechanisms, including hindrance of chain initiation, chelation of metal ions, breakdown of peroxides, sustained hydrogen abstraction, reductive ability and radical scavenging. Hence, numerous methods are proposed to assess the antioxidant activity. DPPH is an extensively used model system to evaluate the free radical scavenging potential of drugs [38]. DPPH radicals are scavenged by antioxidants through the donation of hydrogen, thus forming reduced DPPH-H, which change the color from purple to yellow following reduction and is quantified by analyzing absorbance at wavelength $517 \mathrm{~nm}$ [39]. The ABTS 
Table 1 ABTS free Radical scavenging assay of plant extracts using ascorbic acid as standard

\begin{tabular}{|c|c|c|c|}
\hline Samples & $\begin{array}{l}\text { Concentrations } \\
(\mu \mathrm{g} / \mathrm{ml})\end{array}$ & $\begin{array}{l}\text { Percent inhibition } \\
\text { (mean } \pm \text { SEM) }\end{array}$ & $\begin{array}{l}\mathrm{IC}_{50} \\
(\mu \mathrm{g} / \mathrm{ml})\end{array}$ \\
\hline \multirow[t]{6}{*}{$\mathrm{Ph} . \mathrm{Cr}$} & 1000 & $88.58 \pm 1.12$ & $<0.01$ \\
\hline & 500 & $87.65 \pm 1.34$ & \\
\hline & 250 & $84.31 \pm 2.15$ & \\
\hline & 125 & $77.56 \pm 1.73^{*}$ & \\
\hline & 1000 & $88.44 \pm 0.58$ & \\
\hline & 500 & $87.90 \pm 0.96$ & \\
\hline \multirow[t]{4}{*}{ Ph.Hex } & 250 & $86.28 \pm 2.19$ & $<0.01$ \\
\hline & 125 & $81.77 \pm 1.24$ & \\
\hline & 1000 & $89.76 \pm 0.71$ & \\
\hline & 500 & $87.65 \pm 1.32$ & \\
\hline \multirow[t]{4}{*}{ Ph.Chf } & 250 & $84.23 \pm 1.83$ & $<0.01$ \\
\hline & 125 & $79.10 \pm 0.90^{*}$ & \\
\hline & 1000 & $90.56 \pm 1.06$ & \\
\hline & 500 & $87.42 \pm 0.43$ & \\
\hline \multirow[t]{4}{*}{ Ph.EtAc } & 250 & $86.42 \pm 0.46$ & $<0.01$ \\
\hline & 125 & $80.90 \pm 1.55$ & \\
\hline & 1000 & $91.03 \pm 0.35$ & \\
\hline & 500 & $90.08 \pm 0.47$ & \\
\hline \multirow[t]{4}{*}{ Ph.Bt } & 250 & $87.91 \pm 0.88$ & $<0.01$ \\
\hline & 125 & $83.80 \pm 1.50$ & \\
\hline & 1000 & $90.56 \pm 1.06$ & \\
\hline & 500 & $90.08 \pm 0.47$ & \\
\hline \multirow[t]{4}{*}{ Ph.Aq } & 250 & $87.91 \pm 0.88$ & $<0.01$ \\
\hline & 125 & $83.80 \pm 1.50$ & \\
\hline & 1000 & $90.84 \pm 0.30$ & \\
\hline & 500 & $88.72 \pm 1.01$ & \\
\hline \multirow[t]{4}{*}{ Ph.Sp } & 250 & $87.94 \pm 1.13$ & $<0.01$ \\
\hline & 125 & $79.80 \pm 0.90^{*}$ & \\
\hline & 1000 & $87.90 \pm 0.96$ & \\
\hline & 500 & $83.08 \pm 0.47$ & \\
\hline \multirow[t]{2}{*}{ Ascorbic acid } & 250 & $79.85 \pm 2.24$ & $<0.1$ \\
\hline & 125 & $77.40 \pm 0.20$ & \\
\hline
\end{tabular}

Values significantly different as compare to positive control, ${ }^{*} \mathrm{P}<0.05$. Values expressed as Percent inhibition (Mean \pm SEM of $n=3$ ) and $I_{50}$.

assay is based on the antioxidant capacity of the samples to prevent the oxidation of ABTS to $\mathrm{ABTS}^{++}$radical cation.

Phenolics are a class of antioxidant compounds which function as free radical terminators [15]. Previous reports indicate that the free radicals scavenging efficiency of phenolics is dependent on their molecular weight, presence of aromatic rings and nature of $\mathrm{OH}$ group's substitution [40]. Figure 1 shows extraction yield
Table 2 AChE inhibitory potential of plant extracts

\begin{tabular}{|c|c|c|c|}
\hline Samples & $\begin{array}{l}\text { Concentrations } \\
(\mu \mathrm{g} / \mathrm{ml})\end{array}$ & $\begin{array}{l}\text { Percent inhibition } \\
\text { (mean } \pm \text { SEM) }\end{array}$ & $\begin{array}{l}\mathrm{IC}_{50} \\
(\mu \mathrm{g} / \mathrm{ml})\end{array}$ \\
\hline \multirow[t]{4}{*}{$\mathrm{Ph} . \mathrm{Cr}$} & 1000 & $86.87 \pm 1.27$ & 330 \\
\hline & 500 & $80.62 \pm 1.67^{* *}$ & \\
\hline & 250 & $31.31 \pm 0.58^{* * *}$ & \\
\hline & 125 & 27. $22 \pm 1.28^{* * *}$ & \\
\hline \multirow[t]{4}{*}{ Ph.Hex } & 1000 & $87.49 \pm 0.60$ & 35 \\
\hline & 500 & $76.28 \pm 1.94^{* *}$ & \\
\hline & 250 & $70.08 \pm 1.04^{* * *}$ & \\
\hline & 125 & $65.37 \pm 0.56^{* * *}$ & \\
\hline \multirow[t]{4}{*}{ Ph.Chf } & 1000 & $84.76 \pm 0.61$ & 55 \\
\hline & 500 & $81.36 \pm 1.31^{* *}$ & \\
\hline & 250 & $66.27 \pm 1.06^{* * *}$ & \\
\hline & 125 & $61.17 \pm 1.30^{* * *}$ & \\
\hline \multirow[t]{4}{*}{ Ph.EtAc } & 1000 & $79.95 \pm 2.01^{* *}$ & 310 \\
\hline & 500 & $58.89 \pm 4.82^{* * *}$ & \\
\hline & 250 & $46.22 \pm 1.28^{* * *}$ & \\
\hline & 125 & $40.51 \pm 0.54^{* * *}$ & \\
\hline \multirow[t]{4}{*}{ Ph.Bt } & 1000 & $75.52 \pm 3.28^{* *}$ & 240 \\
\hline & 500 & $55.59 \pm 3.28^{* * *}$ & \\
\hline & 250 & $50.83 \pm 1.21^{* * *}$ & \\
\hline & 125 & $45.87 \pm 0.85^{* * *}$ & \\
\hline \multirow[t]{4}{*}{ Ph.Aq } & 1000 & $67.60 \pm 1.63^{* * *}$ & 100 \\
\hline & 500 & $64.42 \pm 1.89^{* * *}$ & \\
\hline & 250 & $58.25 \pm 1.40^{* * *}$ & \\
\hline & 125 & $51.10 \pm 0.60^{* * *}$ & \\
\hline \multirow[t]{5}{*}{ Ph.Sp } & 1000 & $87.58 \pm 0.63$ & 108 \\
\hline & 500 & $86.61 \pm 0.43$ & \\
\hline & 250 & $60.93 \pm 0.67^{* * *}$ & \\
\hline & 125 & $53.65 \pm 0.91^{* * *}$ & \\
\hline & 1000 & $95.83 \pm 1.21$ & \\
\hline \multirow[t]{3}{*}{ Galanthamine } & 500 & $93.58 \pm 0.63$ & $<0.1$ \\
\hline & 250 & $87.45 \pm 0.90$ & \\
\hline & 125 & $83.08 \pm 1.04$ & \\
\hline
\end{tabular}

Result expressed as $\%$ inhibition (mean \pm SEM of $n=3$ ) and $I_{50}$ values. Values significantly different as compare to positive control, *:P< $<0.05$, **:P<0.01, ***:P $<0.001$.

of phenolics (mg GAE/g of sample) indicating that Ph.EtAc, Ph.Chf and, Ph.Bt expressed high concentrations of phenolics. Results of DPPH and ABTS scavenging activities well correlates with phenolic content and might be attributed to presence of high molecular phenolics in addition to flavonoids in these fractions of plant. Median inhibitory values $\left(\mathrm{IC}_{50}\right)$ were 3,10 , 15 and $35 \mu \mathrm{g} / \mathrm{ml}$ for Ph.Bt, Ph.Chf, Ph.EtAc and Ph.Sp fractions in DPPH free radical scavenging assay. Likewise 
Table $3 \mathrm{BChE}$ inhibitory potential of plant extracts

\begin{tabular}{|c|c|c|c|}
\hline Samples & $\begin{array}{l}\text { Concentrations } \\
(\mu \mathrm{g} / \mathrm{ml})\end{array}$ & $\begin{array}{l}\text { Percent inhibition } \\
\text { (mean } \pm \text { SEM) }\end{array}$ & $\begin{array}{l}\mathrm{IC} \mathrm{C}_{50} \\
(\mu \mathrm{g} / \mathrm{ml})\end{array}$ \\
\hline \multirow[t]{4}{*}{ Ph.Cr } & 1000 & $75.29 \pm 0.64^{* *}$ & 285 \\
\hline & 500 & $64.72 \pm 0.89^{* * *}$ & \\
\hline & 250 & $47.44 \pm 0.86^{* * *}$ & \\
\hline & 125 & $42.78 \pm 0.45^{* * *}$ & \\
\hline \multirow[t]{4}{*}{ Ph.Hex } & 1000 & $90.30 \pm 1.42$ & 40 \\
\hline & 500 & $84.80 \pm 0.41^{*}$ & \\
\hline & 250 & $69.51 \pm 0.59^{* * *}$ & \\
\hline & 125 & $65.90 \pm 0.32^{* * *}$ & \\
\hline \multirow[t]{4}{*}{ Ph.Chf } & 1000 & $85.94 \pm 0.91^{*}$ & 215 \\
\hline & 500 & $62.93 \pm 1.73^{* * *}$ & \\
\hline & 250 & $51.82 \pm 0.95^{* * *}$ & \\
\hline & 125 & $46.68 \pm 0.22^{* * *}$ & \\
\hline \multirow[t]{4}{*}{ Ph.EtAc } & 1000 & $81.01 \pm 0.97^{* *}$ & 395 \\
\hline & 500 & $59.05 \pm 1.03^{* * *}$ & \\
\hline & 250 & $34.54 \pm 0.60^{* * *}$ & \\
\hline & 125 & $29.88 \pm 0.89^{* * *}$ & \\
\hline \multirow[t]{4}{*}{ Ph.Bt } & 1000 & $76.92 \pm 1.15^{* *}$ & 415 \\
\hline & 500 & $58.89 \pm 1.73^{* * *}$ & \\
\hline & 250 & $21.65 \pm 2.41^{* * *}$ & \\
\hline & 125 & 18. $20 \pm 0.47^{* * *}$ & \\
\hline \multirow[t]{4}{*}{$\mathrm{Ph} . \mathrm{Aq}$} & 1000 & $87.62 \pm 1.42$ & 3 \\
\hline & 500 & $84.79 \pm 1.88$ & \\
\hline & 250 & $80.79 \pm 1.08^{*}$ & \\
\hline & 125 & $75.12 \pm 0.54^{* *}$ & \\
\hline \multirow[t]{4}{*}{ Ph. Sp } & 1000 & $76.32 \pm 0.87^{* *}$ & 330 \\
\hline & 500 & $74.33 \pm 0.66^{* *}$ & \\
\hline & 250 & $35.40 \pm 0.82^{* * *}$ & \\
\hline & 125 & $30.90 \pm 0.45^{* * *}$ & \\
\hline \multirow[t]{4}{*}{ Galantamine } & 1000 & $96.00 \pm 0.30$ & $<0.1$ \\
\hline & 500 & $92.90 \pm 0.60$ & \\
\hline & 250 & $89.45 \pm 0.90$ & \\
\hline & 125 & $86.23 \pm 0.22$ & \\
\hline
\end{tabular}

Result expressed as \% inhibition cmean \pm SEM of $n=3$ ) and $\mathrm{IC}_{50}$ values. Values significantly different as compare to positive control, *:P<0.05, ${ }^{* *}: P<0.01$, ***:P $<0.001$

the $\mathrm{IC}_{50}$ values for all fractions in $\mathrm{ABTS}$ assay were $<0.01$ which are comparable to positive control galantamine $\left(\mathrm{IC}_{50}<0.01\right)$ Figure 3 and Table 1. Our findings indicate that $P$. hydropiper is enriched with antioxidant compounds and show its possible effectiveness in the management of free radicals induced disorders especially neurodegenerative diseases.

Medicinal plants having therapeutic potential for the treatment of neurodegenerative diseases like AD, Epilepsy and Parkinsonism have been extensively explored,

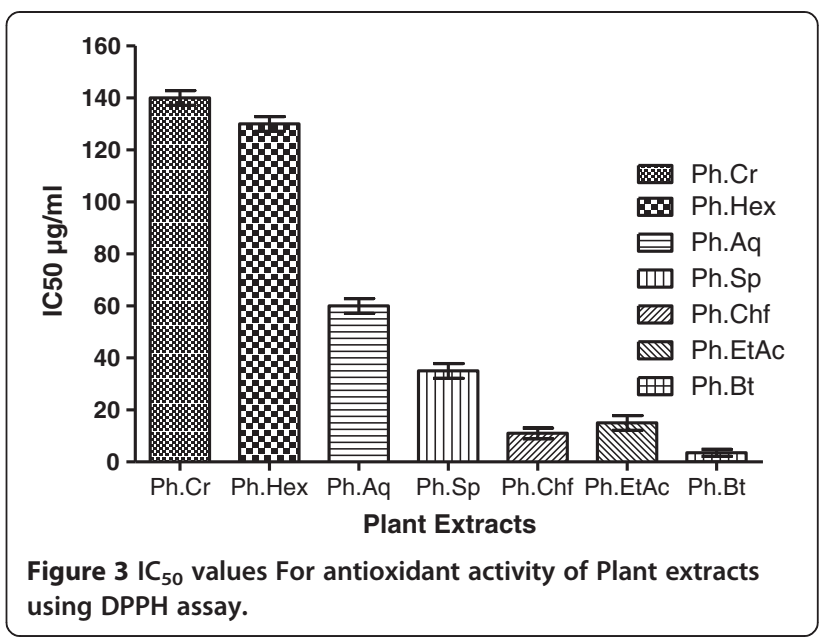

still there is a continuous search for new drugs like galanthamine $[24,41]$. There are several reports which specify the biological potential of plants as AChE inhibitors in-vitro as well as memory enhancers in-vivo [41,42]. Table 2 shows AChE inhibitory activity (\%) and $\mathrm{IC}_{50}$ values of the plant extracts. All fractions showed concentration dependent AChE inhibitory activity. Results of the current study revealed that Ph.Hex was most effective against $\mathrm{AChE}$ causing $87.49 \%$ enzyme inhibition with $\mathrm{IC}_{50} 35 \mu \mathrm{g} / \mathrm{ml}$. Other fractions were also effective at $1 \mathrm{mg} / \mathrm{ml}$ concentration. The concentrations of the crude plant extracts that inhibited BChE activity by $50 \%$ $\left(\mathrm{IC}_{50}\right)$ are presented in the Table. Our results indicate that $P$. hydropiper extracts are equally effective against $\mathrm{BChE}$. The strongest $\mathrm{BChE}$ inhibitory activities were exhibited by Ph.Aq and Ph.Hex fractions, causing 87.62 and $90.30 \%$ inhibition with $\mathrm{IC}_{50}$ values of 3 and $40 \mu \mathrm{g} / \mathrm{ml}$ respectively.

\section{Conclusions}

In the light of our findings, it can be concluded that most fractions of our plant screened herein exhibited high antioxidant potential and can be related to presence of high molecular weight phenolics. The plant has also showed inhibitory activity against $\mathrm{AChE} \& \mathrm{BChE}$ enzymes in dosedependent way. This warrant further investigations to exploit the potential use of the bioactive compounds in the treatment of neurodegenerative diseases. Further research linked to the isolation of the bioactive compounds via bioassay-guided isolation is in progress in our laboratory.

\section{Abbreviations}

(Ph.Cr): Crude methanolic extract of P. hydropiper; (Ph.Hex): $n$-hexane fraction of P. hydropiper; (Ph.Chf): chloroform fraction of P. hydropiper; (Ph.EtAc): Ethyl acetate fraction of $P$. hydropiper; (Ph.Bt): $n$-Butanol fraction of $P$. hydropiper; (Ph.Aq): Aqueous fraction of $P$. hydropiper; (Ph.Sp): Saponins fraction of P. hydropiper; (AChE): Acetylcholinesterase (BChE), Butyrylcholinesterase; (BHT): Butylated hydroxy toluene; (BHA): Butylated hydroxy anisole; (ACh): Acetylcholine; (AD): Alzheimer's disease; (FCR): Folin Ciocalteu reagent. 


\section{Competing interests}

The authors declare that they have no competing interest.

\section{Authors' contributions}

MA and SA carried out experimental work, data collection and evaluation, literature search and manuscript preparation. MJ and FU supervised research work. JA, AS and MI refined the manuscript for publication. All authors read and approved the final manuscript for publication.

\section{Acknowledgements}

The authors sincerely thank Dr. Gul Rahim for identification of the plant. The authors also want to thank University of Malakand for providing laboratory facilities to conduct the research.

\section{Funding}

This research received no specific grant from any funding agency in the public, commercial, or not-for-profit sectors.

\section{Author details}

'Department of Pharmacy, University of Malakand, Khyber Pakhtoonkhwa 18000, KPK, Pakistan. ${ }^{2}$ Institute of Basic Medical Sciences (IBMS), Khyber Medical University (KMU), Peshawar, Pakistan.

Received: 24 January 2014 Accepted: 30 April 2014 Published: 3 May 2014

\section{References}

1. Farnsworth N, Akerele O, Bingel A, Soejarto D, Guo Z: Medicinal plants in therapy. Bull WHO 1985, 63(6):965-981.

2. Sharma R: Medicinal plants of India-An encyclopedia. In Daya Publishing House, 110035 Delhi, India; 2003:46-47.

3. Foster S, James AD: A field guide to medicinal plants: Eastern and central North America. In Peterson Field Guide Series, $2^{\text {nd }}$ edition, Houghton Mifflin Park Avenue, New York 10003; 1990:241.

4. Chevallier A: The encyclopedia of medicinal plants. In Dorling Kindersley London. London: Andrew DK Publishing; 1996:185. ISBN 9-780751-303148.

5. Peng ZF, Strack D, Baumert A, Subramaniam R, Goh NK, Chia TF, Ngin Tan S, Chia LS: Antioxidant flavonoids from leaves of Polygonum hydropiper L. Phytochemistry 2003, 62(2):219-228.

6. Chan Y-C, Wang M-F, Chen Y-C, Yang D-Y, Lee M-S, Cheng F-C: Long-term administration of polygonum multiflorum thunb: reduces cerebral ischemia-induced infarct volume in gerbils. Am J Chin Med 2003, 31(1):71-77.

7. Chen LW, Wang YQ, Wei LC, Shi M, Chan YS: Chinese herbs and herbal extracts for neuroprotection of dopaminergic neurons and potential therapeutic treatment of parkinsons disease. CNS Neurol Disord Drug Targets 2007, 6(4):273-281.

8. Li X, Matsumoto K, Murakami Y, Tezuka Y, Wu Y, Kadota S: Neuroprotective effects of Polygonum multiflorum on nigrostriatal dopaminergic degeneration induced by paraquat and maneb in mice. Pharmacol Biochem Behav 2005, 82(2):345-352.

9. Kumpulainen J, Salonen J: Natural antioxidants and anticarcinogens in nutrition, health and disease. R Soc Chem UK 1999, 240:178-187.

10. Shah SM, Ayaz M, Khan A-u, Ullah F, Shah a-u-HA, lqbal H, Hussain S: 1,1Diphenyl,2-picrylhydrazyl free radical scavenging, bactericidal, fungicidal and leishmanicidal properties of Teucrium stocksianum. Toxicol Ind Health 2013, doi:10.1177/0748233713487250.

11. Halliwell B: Free radicals, antioxidants, and human disease: curiosity, cause, or consequence? Lancet 1994, 344:721-724.

12. Kuhnan J: The flavonoids. A class of semi-essential food components; their role in human nutrition. World Rev Nutr Diet 1976, 24:117-191.

13. Barlow A, Susan M: Toxicological aspects of antioxidants used as food additives. In Food Antioxidants. Netherlands: Springer; 1990:253-307.

14. Kil HY, Seong ES, Ghimire BK, Chung IM, Kwon SS, Goh EJ, Hoe K, Kim MJ, Lim JD, Lee D, Yu CY: Antioxidant and antimicrobial activities of crude sorghum extract. Food Chem 2009, 115:1234-1239.

15. Shahidi F, Wanasundara P: Phenolic antioxidants. Crit Rev Food Sci Nutr 1992, 32:67-103
16. Atta-ur R, Wahab A, Nawas S, Choudhary M: New cholinesterase inhibiting bisbenzylisoquinoline alkaloids from Cocculus pendulus. Chem Pharm Bull 2004, 52:802-806.

17. Ahmad W, Ahmad B, Ahmad M, lqbal Z, Nisar M, Ahmad M: In vitro inhibition of acetylcholinesterase, buty-rylcholinesterase and lipoxygenase by crude extract of Myricaria elegans Royle. J Biol Sci 2003, 11:1046-1049.

18. Jann MW: Preclinical pharmacology of metriphonate. Pharmacotherapy 1998, 18:55-67.

19. Aisen PS, Davis KL: The search for disease-modifying treatment for Alzheimer's Disease. Neurology 1997, 48:35-41.

20. Bachman DL, Wolf PA, Linn RT: Prevalence of dementia and probable senile dementia of the Alzheimer's type in the Framingham study. Neurology 1992, 42:115-119.

21. Voet D, Voet JG: Serine proteases. In Biochemistry. 2nd edition. USA: John Wiley and Sons; 1995:390.

22. Knapp MJ, Knopman DS, Solomon PR, Pendlebury WW, Davis CS, Gracon SI: A 30-week randomized controlled trial of high-dose tacrine in patients with Alzheimer's disease.The Tacrine study group. J Am Med Assoc 1994, 271:985-991.

23. Schneider LJ: Treatment of Alzheimer's disease with cholinesterase inhibitors. Clin Geriatr Med 2001, 17(2):337-58.

24. Heinrich M, Teoh HL: Galanthamine from snowdrop-the development of a modern drug against Alzheimer's disease from local Caucasian knowledge. J Ethnopharmacol 2004, 92:147-162.

25. Perry NSL, Houghton PJ, Theobald A, Jenner P, Perry EK: In-vitro inhibition of human erythrocyte acetylcholinesterase by Salvia lavandulaefolia essential oil and constituent terpenes. J Pharm Pharmacol 2000, 52:895-902.

26. Konan AB, Datte JY, Yapo P: Nitric oxide pathway-mediated relaxant effect of aqueous sesame leaves extract (Sesamum radiatum Schum. \& Thonn.) in the guinea-pig isolated aorta smooth muscle. BMC Complement Altern Med 2008, 8:23.

27. Khan FA, Ullah Z, Haider S: Phytochemicals screening and antimicrobial activities of selected medicinal plants of Khyber pakhtunkhwa Pakistan. Afr J Pharm Pharmacol 2011, 5(6):746-750.

28. Kim D, Jaeong S, Lee C: Antioxidant capicity of phenolic phytochemicals from various cultivars of plums. Food Chem 2003, 81:321-326.

29. Braca A, Tommasi ND, Bari LD, Pizza C, Politi M, Morelli I: Antioxidant principles from Bauhinia terapotensis. J Nat Prod 2001, 64(7):892-895.

30. Re R, Pellegrini N, Proteggente A, Pannala A, Yong M, Rice-Evas C: Antioxidant activity applying an improved FBTS radical cation decolorization assay. Free Rad Biol Med 1999, 26(9/10):1231-1237.

31. Trevisan MTS, Macedo FW, Meent M, Rhee IK, Verpoorte R: Screening for acetylcholinesterase inhibitors from plants to treat Alzheimer's disease. QuÃmica Nova 2003, 26(3):301-304.

32. Classics Ellman GL, Courtney KD, Andres V, Featherstone RM: A new and rapid colorimetric determination of acetylcholinesterase activity. Biochem Pharmacol 1961, 7:88-95.

33. Aruoma O: Methodological considerations for characterizing potential antioxidant actions of bioactive components in food plants. Mutat Res 2003, 9(20):523-524.

34. Jadhav H, Bhutani K: Antioxidant properties of Indian medicinal plants. Phytother Res 2002, 16(8):771-773.

35. Yildirim A, Mavi A, Oktay M, Kara A, Algur O, Bilaloglu V: Comparison of antioxidant and antimicrobial activities of tilia (Tilia argenta Desf Ex DC), sage (Salvia triloba L.) and black tea (Camellia sinensis) extracts. J Agric Food Chem 2000, 48(10):5030-5034.

36. Hasan S, Hossain M, Akter R, Jamila M, Mazumder M, Rahman S: DPPH free radical scavenging activity of some Bangladeshi medicinal plants. $J$ Med Plants Res 2009, 3(11):875-879.

37. Saeed S, Urfi M, Ali T, Khimani F, Gilani A: Antioxidants: their role in health and disease. Int J Pharmacol 2005, 1(3):210-217.

38. Bashir S, Gilani A: Studies on the antioxidant and analgesic activities of Aztec marigold (Tagetes erecta) flowers. Phytother Res 2008, 22(12):1692-1694

39. Soare J, Dinis T, Cunha A, Almeida L: Antioxidant activities of some extracts of Thymus zygis. Free Radic Res 1997, 26(5):469-478.

40. Hagerman A, Riedl K, Jones G, Sovik K, Ritchard N, Hartzfeld P: High molecular weight plant polyphenolics (Tannins) asbiological antioxidants. J Agric Food Chem 1998, 46:1887-1892. 
41. Ingkaninan K, Temkitthawon P, Chuenchon K, Yuyaem T, Thongnoi W: Screening for acetylcholinesterase inhibitory activity in plants used in Thai traditional rejuvenating and neurotonic remedies. J Ethnopharmacol 2003, 89:261-264.

42. Tildesley NTJ, Kennedy DO, Perry EK, Ballard CG, Savelev S, Sesnes KA, Scholey AB: Salvia lavandulaefolia (Spanish sage) enhances memory in healthy young volunteers. Pharmacol Biochem Behav 2003, 75:669-674.

doi:10.1186/1472-6882-14-145

Cite this article as: Ayaz et al: Phenolic contents, antioxidant and

anticholinesterase potentials of crude extract, subsequent fractions and crude saponins from Polygonum hydropiper L. BMC Complementary and Alternative Medicine 2014 14:145.

\section{Submit your next manuscript to BioMed Central and take full advantage of:}

- Convenient online submission

- Thorough peer review

- No space constraints or color figure charges

- Immediate publication on acceptance

- Inclusion in PubMed, CAS, Scopus and Google Scholar

- Research which is freely available for redistribution 